УДК 658.513.012.12

С.К. Мещанінов, д.т.н. професор

Дніпровський державний технічний університет, м. Кам’янське

\title{
МОДЕЛЬ СИСТЕМИ ЕЛЕКТРОННОГО БІОМЕТРИЧНОГО КОНТРОЛЮ НАДІЙНІСТЮ ФУНКЦІОНУВАННЯ ЛЮДИНО-МАШИННОЇ СИСТЕМИ
}

Приведені дані аналітичних досліджень електронної системи в комплексі біометричного контролю надійності функиіонування складної технічної системи на прикладі очисного вибою сучасної вугільної шахти. Розглянута поведінка системи "Людина-машина-середовище" на основі вивчення психофізіологічних особливостей поведінки людини в екстремальних умовах сучасного виробництва. Зроблений висновок про ті, що для підвищення рівня промислової безпеки при експлуатації ваэсливих і потенційно небезпечних виробничих об'єктів повинний існувати певний мінімум біометричних параметрів, контрольованих безперервно (y оn-line режимі).

Ключові слова: людський чинник, біометричний контроль, складна технічна система, виробничий об'єкт.

There are presented the data of analytical researches of the electronic system of in the biometric control complex of functioning reliability the difficult technical system on the example of modern coal mine working out. Are considered the behavior of system "Man - machine - environment" on the basis of study of psihfisiological features man's behavior in the extreme terms of modern production. Made the conclusion that for the increase of industrial stafety during exploitation the important and potentially dangerous industrial objects must to exist a certain minimum of biometric parameters, controlled continuously (in on-line).

Keywords: human factor, biometric control, difficult technical system, productive object.

\section{Постановка проблеми}

При експлуатації складних машин і комплексів людина і машина стають об'єднаними в одну складну технічну систему (СТC). В процесі ії функціонування в підсистемі «Людинамашина-середовище» відбувається пристосування (взаємодія) людини і інших іiі підсистем, внаслідок чого надійність функціонування в цілому по системі може бути, як підвищена, так і знижена. Підсистема «Людина-машина-середовище» є відновлюваним і обслуговуваним. Тому вона має структурне, інформаційне і функціональне резервування і їі надійність в цілому може бути вища за надійність інших підсистем СТС. Працездатність і надійність підсистеми «Людина-машина-середовище» значною мірою залежать від психофізіологічних особливостей людини і від пристосованості машин до взаємодії з людиною. Тобто, потрібний біометричний контроль фізіологічних і психологічних можливостей людини нести певні навантаження і перевантаження, сприймати і передавати необхідну інформацію, знаходитися в цій ситуації або умовах необхідний час і тому подібне. Прикладом сучасної СТС є очисний забій вугільної шахти. Вирішення питань безпеки особливе важливо при експлуатації очисного вироблення, працюючого в режимі підвищених навантажень, коли відмова одного з елементів такої системи може привести до катастрофічних наслідків.

Ергономічні властивості людини є комплексом антропометричних, фізіологічних і психологічних його властивостей. Питання впливу людського чинника на рівень безпеки при роботі СТС досить детально розглянуті в роботі [1].

\section{Аналіз останніх досліджень і публікацій}

Аналіз причин травматизму в комплексно-механізованих лавах, за даними роботи [2], показує, що питома доля травм в результаті ушкодження машинами і механізмами складає близько $30 \%$. 3 них близько 50\% доводиться на суб'єктивні причини: знаходження в небезпечній зоні (14,3\%), помилкові дії (6-12\%), неузгодженість дій $(2,9-10,2 \%)$, проведення непередбачених робіт $(2-3 \%)$. 
Очисний забій сучасної вугільної шахти як СТС є сукупністю таких підсистем, як «Атмосфера», «Технологічне устаткування», «Приконтурна область» $\mathrm{i}$ «Обслуговуючий персонал», кожна 3 яких складається з набору структурних підсистем, що взаємодіють між собою за схемою послідовно сполучених елементів [3]. При цьому повна інформація про рівень безпеки такої СТС може бути отримана, і по ній здійснені своєчасно операції прогнозу і управління за допомогою комплексної системи контролю і управління надійністю функціонування очисного забою [3]. Однією з підсистем цієї комплексної системи контролю і управління $є$ комплексна система біометричного контролю, обслуговуючого СТС персоналу.

Як вказується в роботі [4], потрібно пам'ятати про двояку роль людину з позицій надійності : з одного боку, людина — це дуже досконала система, він може оцінювати складну обстановку і приймати такі рішення, які не здатна прийняти ніяка машина, що управляє; з іншого боку, людина сама схильна до «відмов», якщо на його нервову систему і на фізичний стан діють неприпустимі перевантаження.

Особливі проблеми має система колектив - комплекс машин - очисне вироблення. У ній, окрім вже перерахованих чинників, провідну роль грають соціальні стосунки, ієрархія окремих виконавців, організаційна структура підрозділу, ідеологія і взаємовідносини людей, системи управління якістю і надійністю.

\section{Формулювання мети дослідження}

Таким чином, метою справжньої роботи є дослідження значущості людського чинника в роботі комплексної системи біометричного контролю надійності функціонування СТС на прикладі очисного забою сучасної вугільної шахти.

\section{Виклад основного матеріалу}

Однією з головних психофізіологічних особливостей праці гірників $є$ висока міра їх професійного ризику. Це пов'язано з виникненням частих конфліктних ситуацій, що створюються суперечливими мотивами поведінки в складній виробничій обстановці. Аналіз ризикованих дій людини показав, що у гірників вугільних шахт часто зустрічаються наступні мотиви [1]:

- зневажливе відношення до ризику;

- недисциплінованість;

- звичка до небезпеки;

- переоцінка своїх можливостей.

Модель людино-машинної системи представлена на малюнку.

Стомлення, що розвивається в процесі праці, сприяє вибору неправильного рішення, у виборі між виконанням роботи безпечним способом або ії виконанням з меншими зусиллями i терміном, але з великим ризиком. Надмірна тяжкість окремих операцій, дефіцит часу на їх виконання частенько роблять скрутним дотримання обережності, а пам'ять про додаткові зусилля, необхідні для застосування засобів безпеки (підкріплена роботою без травм), виправдовує ризиковані дії.

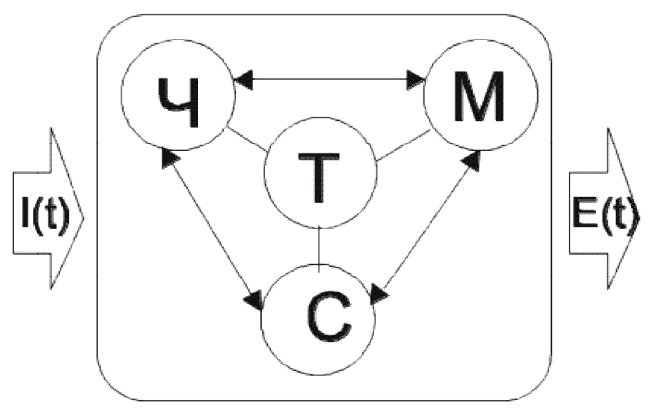

Рис. 1. Модель людино-машинної системи: Ч — людина; $\mathrm{M}$ - машина; $\mathrm{C}$ - робоче середовище, які пов'язані між собою і зовнішнім (для усієї системи) середовищем за допомогою технології (Т); вхідне інформаційно-матеріальне обурення (команди, що управляють, на машини і механізми) 
Слід зазначити, що людина, на відміну від автоматики, не поводиться раціонально. Більше того, він здійснює інтуїтивно пошук рішень, які відповідають статистичним критеріям, або робить заміщення підмета рішенню процесу асоціацією з деякою раніше наявною ситуацією, для якої у нього відклалося в пам'яті рішення по колишньому досвіду. Таке рішення, проте, можливо тільки на базі відповідної ментальної моделі поведінки системи.

Разом з вище переліченими здібностями, людина як частину підсистеми «Людинамашина-середовище» проявляє істотні недоліки:

- обмеженість пам'яті;

- відсутність або наявність ментальної моделі з помилками;

- обмежена надійність;

- недостатня постійність працездатності, особливо, при тривалій роботі;

- упередженість і фіксованість;

- недостатня ментальна арифметика;

- обмежена смуга пропускання при ручних реагуваннях.

За даними роботи [1], існує три типи поведінки людини :

- що базується на знаннях;

- що базується на правилах;

- що базується на готовності.

Рівень автоматизації людино-машинної системи [1]:

$$
y A=\frac{F_{a в m}}{F_{a b m+p y ч н}},
$$

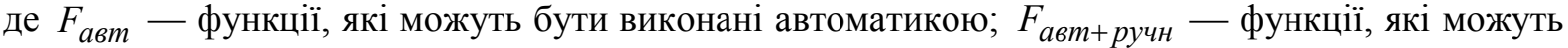
бути виконані або людиною, або автоматикою.

Тоді максимально можливий рівень автоматизації, коли автоматизовано максимально можливе число функцій [1]:

$$
\text { У } A_{\text {max }}=\frac{F_{a в m+\text { ручн }}-F_{\text {ручн }}}{F_{\text {авт+ }} \text { ручн }} .
$$

Поняття «Людські відмови» є як би перетворенням факту, що людина зі своїми природженими і придбаними здібностями і слабкостями недостатньо враховується при проектуванні технічних систем. Тому актуальне завдання так спроектувати таку систему «Людина-машинасередовище», щоб вона максимально «зважала» на людину. У цій ситуації можна стверджувати, що людина вимушена йти на компроміс з гірськими машинами, механізованим комплексом і очисним забоєм в цілому, внаслідок чого з'являється можливість для оптимізації. Справедливо і зворотне: СТС (очисне вироблення) також повинна «пристосовуватися» до особливостей людей, iї обслуговуючих. Останнє твердження говорить про можливість оптимізації системи (очисний забій) по відношенню до людини. Таким чином, є дві можливості для оптимізації:

перша - з боку людини по відношенню до очисного забою;

друга - 3 боку очисного вироблення по відношенню до людини, у зв'язку з чим, можуть бути побудовані дві цільові функції.

Взагалі кажучи, правильніше поняття «Людська відмова» замінити поняттям «Помилка обслуговування».

До головних причин помилок обслуговування можна віднести [1]:

- ситуаційні чинники (незручне компонування, робоче місце, навколишнє оточення, інформаційний контроль);

- фізичні, емоційні, соціальні і організаційні чинники (стомленість, хвороба, стрес, негативний виробничий клімат, погана навчена персоналу);

- неправильне сприйняття ризику.

Зроблені в роботі [5] висновки про негативний вплив на людину дискомфортних умов праці в кам'яновугільних шахтах дозволяють стверджувати, що цей вплив не може бути врахований детермінованим чином. 
При обліку людського чинника необхідно приділяти особливу увагу обробці і ущільненню (стискуванню) такою, що поступає від контролюючих підсистем і центрального комплексу інформації, що інформаційно-управляє. Це необхідно для того, щоб людина-оператор і обслуговуючий очисне вироблення персонал могли адекватно і своєчасно засвоїти потік інформації, що поступає, і прийняти на цій основі правильні рішення. Для досягнення такого ефекту ущільнення інформації повинне відповідати ряду вимог, які можна сформулювати таким чином:

1. Визначеність. Людина повинна отримувати конкретну інформацію, відповідно до якої необхідно робити цілком конкретні і однозначні дії. Інформація, що поступає, не повинна давати приводів для коливань або бути хоч би в якійсь мірі двозначній.

2. Оборотність. У разі потреби інформаційне повідомлення повинне мати можливість бути розгорнутим для детальнішого аналізу причин, що його, що створили.

3. Показність. Інформація, що поступає, має бути у формі, яка не зможе бути залишеною без уваги. Для очисного вироблення це, мабуть, має бути система світлової і звукової сигналізації, розміщена на пункті, що контрольний-управляє, і безпосередньо на робочих місцях.

Оцінку надійності і безпеки СТС зручно здійснити, не враховуючи наступні загальні стани:

- виробнича діяльність потенційно небезпечна, оскільки пов'язана з проведенням технологічних процесів, а останні - 3 енергоспоживанням (виробленням, зберіганням, перетворенням механічної, електричної, хімічної, ядерної і іншій енергії).

- небезпека проявляється в результаті несанкціонованого або некерованого виходу енергії, накопиченої в устаткуванні і/або шкідливих речовинах, безпосередньо в самих працюючих, в зовнішньому відносно людей і техніка середовищі.

- раптовий вихід енергії може супроводжуватися подіями із загибеллю або травмуванням людей, ушкодженнями устаткування або об'єктів природного середовища, що оточує їх.

- подіям передують ланцюги передумов, управління, що призводять до втрати, технологічним процесом, небажаному викиду використовуваних в нім енергії або шкідливих речовин, ïx дії на людей, устаткування і довкілля.

- ланками причинного ланцюга події є помилкові і несанкціоновані дії персоналу, несправності і відмови техніки, а також нерозрахункові дії на них ззовні.

До людини-оператора у даному контексті, а також і в певному значенні, i до усього обслуговуючого очисний забій персоналу, окрім вимог, обумовлених безпосередніми виробничими завданнями, має бути пред'явлений наступний набір вимог : безпомилковість, готовність, відновлюваність, своєчасність, точність сприйняття і реагування на інформацію, що поступає. Відповідно до цього потрібні додаткові заходи по професійному відбору осіб, обслуговуючих очисний забій.

У тому або іншому ступені, як оператори в очисному виробленні працюють усі гірники. До чинників, що обумовлюють помилки в роботі оператора, і ведучим до підвищення небезпеки ведення робіт, слід віднести [1]:

- недолік інформації про аварії;

- дефіцит часу на ухвалення рішень;

- неадекватна реакція в стресовій ситуації (вплив стресу посилюється страхом, обумовленим підвищеною відповідальністю, невпевненістю в собі, недоліком знань і досвіду).

Очевидно, що частина цих помилок, причини яких не пов'язані з індивідуальними особовими якостями, може бути виключена в результаті навчання і спеціальних тренінгів.

\section{Висновки та перспективи подальших досліджень}

Таким чином, можна стверджувати, що:

- повний і однозначний прогноз рівня безпеки при веденні робіт в очисному виробленні по людському чиннику неможливий в силу специфіки психофізіологічних характеристик людини;

- в якості контрольованих параметрів по цьому чиннику можуть бути використані чисельність працюючих, їх вік і кваліфікація, яка повинна оцінюватися за спеціальною шкалою; 
- основним шляхом підвищення рівня безпеки в очисному забої по людському чиннику, являється проведення навчально - тренувальних занять з обслуговуючим очисний забій персоналом і регулярний контроль його психофізіологічних характеристик.

У загальному випадку, підсистема «Обслуговуючий персонал» являється, значною мірою специфічною. Проте, незважаючи на це, їі функціонування можна розглядати з системотехнічних позицій, як і функціонування усіх інших підсистем очисного забою. Найбільше функціонування цієї підсистеми схоже з функціонуванням підсистеми «Технологічне устаткування». Дійсно, підсистема «Обслуговуючий персонал» робить за допомогою завдання режимів роботи технологічного устаткування пряма дія на приконтурну область масиву, змінюючи його стан.

Очевидно, що вихід за деякі допустимі межі параметрів підсистеми «Обслуговуючий персонал», спричиняє за собою аналогічні зміни в поведінці окремих підземних робітників. 3 іншого боку, їх неправильні дії можуть спричинити порушення в роботі усієї СТС.

Тоді для оцінки вірогідності надійної роботи підсистеми «Обслуговуючий персонал» можна запропонувати наступний набір інформативних параметрів, який є квазіпостійним (він оновлюється від зміни до зміни):

- число працюючих в очисному забої;

- їх кваліфікацію;

- вік;

- відношення кількості працюючих в очисному виробленні до їх оптимальної (потрібному) кількості,

- інші параметри працюючих, здатні вплинути на безпеку ведення робіт.

Крім того, повинен існувати певний мінімум біометричних параметрів, реєстрованих безперервно (у on-line режимі). До таких можуть бути віднесені: температура тіла людиниоператора, частота дихання і пульсу, можливо, реєстрація акустичного і ІЧ-випромінювання 3 поверхні тіла гірника. На сьогодні, ці виміри не робляться в силу складності їх реалізації у виробничих умовах, а також дорожнечі використовуваної апаратури.

Проте, абсолютно очевидно, що така інформація могла б стати однією з ключових ланок на шляху до вирішення проблеми підвищення рівня промислової безпеки при експлуатації важливих і потенційно небезпечних виробничих об'єктів.

\section{Список використаної літератури}

1. Человеко-машинные системы автоматизации / [авт. текста В.И. Архангельский, И.Н. Богаенко, Г.Г. Грабовский, Н.А. Рюмшин]. - К.: НВК «КіА», 2000. - 296 с.

2. Безопасность ведения горных работ и горноспасательное дело / [Ушаков К.3., Каледина Н.О., Кирин Б.Ф. и др.]; под общ. ред. К.З. Ушакова - [2-е изд., стереот.] - М.: Изд-во МГУ, 2002. $-487 \mathrm{c}$.

3. Мещанинов С.К. Методы моделирования и управления надежностью функционирования горных выработок [Текст]: моногр. / С.К. Мещанинов. - Национальный горный университет, 2012. $-360 \mathrm{c}$.

4. Проников А.С. Надежность машин / Проников А.С. - М.: Машиностроение, 1978. - 592 с.

5. Герлетка С. Влияние эргономических факторов на электрофизиологию человека // Безопасность труда в промышленности / С. Герлетка - 2003. - № 1. - С. 59-63. 